\title{
3M Plus Cegah Demam Berdarah Di Posyandu Pelita Hati Sidomulyotimur Kota Pekanbaru
}

\author{
Yuyun Priwahyuni \\ Prodi Kesehatan Masyarakat STIKes Hang Tuah Pekanbaru \\ email: yuyun.priwahyuni@gmail.com
}

\begin{abstract}
Dengeu Hemorrhagic Fever (DHF) is one of the public health problems in Indonesia, because the number of sufferers and the area of its spread is increasing along with the increase in mobility and population density. Dengue fever is found in almost all parts of the world, especially in tropical and subtropical countries, which in the last 5 years the number of cases and affected areas continues to increase and spread widely and often causes extraordinary events/outbreaks. WHO data (2015) estimates that 2.5 billion or $40 \%$ of the world's population is at risk of DHF, especially those living in urban areas in tropical and subtropical countries. At present there are also an estimated 390 million dengue infections that occur worldwide each year. The purpose of PKM is to increase the knowledge of mothers in implementing $3 M$ plus Prevent Dengue Fever PKM Method of health education, The method to be used in this PKM is a form of community service in the form of counseling and health education, PKM target for Posyandu Pelita Hati RW 11, Sidomulyo Village, Pekanbaru City. The activity was held on November 15, 2019. The results obtained were that of the 20 mothers who participated in the activity 50\% of the mothers knew and had done $3 M$ plus.
\end{abstract}

Keywords: 3M plus Prevent Dengue Fever, Pelita Hati Posyandu

\begin{abstract}
Abstrak
Demam Berdarah Dengeu (DBD) adalah salah satu masalah kesehatan masyarakat di Indonesia, karena jumlah penderita dan luas penyebarannya semakin meningkat seiring dengan meningkatnya mobilitas dan kepadatan penduduk. Demam berdarah ditemukan di hampir semua bagian dunia, terutama di negara-negara tropis dan subtropis, yang dalam 5 tahun terakhir jumlah kasus dan daerah yang terkena dampak terus meningkat dan menyebar secara luas dan sering menyebabkan peristiwa luar biasa/wabah. Data WHO (2015) memperkirakan bahwa 2,5 miliar atau $40 \%$ populasi dunia berisiko terkena DBD, terutama mereka yang tinggal di daerah perkotaan di negara tropis dan subtropis. Saat ini diperkirakan ada 390 juta infeksi dengue yang terjadi di seluruh dunia setiap tahun. Tujuan PKM adalah untuk meningkatkan pengetahuan ibu dalam menerapkan metode pendidikan kesehatan 3M plus Prevent Dengue Fever PKM, Metode yang akan digunakan dalam PKM ini adalah bentuk pengabdian kepada masyarakat berupa penyuluhan dan pendidikan kesehatan, target PKM untuk Posyandu Pelita Hati RW 11, Desa Sidomulyo, Kota Pekanbaru. Kegiatan ini diadakan pada 15 November 2019. Hasil yang diperoleh adalah bahwa dari 20 ibu yang berpartisipasi dalam kegiatan, 50\% ibu tahu dan telah melakukan 3 M plus.
\end{abstract}

Kata Kunci : 3M Plus Cegah Demam Berdarah, Pelita Hati Posyandu

\section{PENDAHULUAN}

Bakpia merupakan salah satu kuliner Penyakit Demam Berdarah Dengue (DBD) merupakan salah satu masalah kesehatan masyarakat di Indonesia, dikarenakan jumlah penderita dan luas daerah penyebarannya semakin bertambah seiring dengan meningkatnya mobilitas dan kepadatan penduduk 
(Kemenkes RI, 2010). Demam berdarah ditemukan hampir di seluruh belahan dunia terutama negara tropik dan subtropik (Ariani, 2016), yang dalam kurun waktu 5 tahun terakhir jumlah kasus dan daerah terjangkit terus meningkat dan menyebar luas serta sering menimbulkan Kejadian Luar Biasa/KLB (Depkes RI, 2008). Kejadian demam berdarah dapat berpotensi menimbulkan dampak sosial yang berupa keresahan masyarakat karena perjalanan penyakitnya yang cepat dan dapat menyebabkan kematian dalam waktu singkat, serta dampak ekonomi yaitu meningkatnya anggaran belanja negara untuk pengobatan penyakit demam berdarah (Afrian, dkk, 2016).

Data WHO (2015) memperkirakan 2,5 miliar atau $40 \%$ populasi di dunia berisiko terhadap penyakit DBD terutama yang tinggal di daerah perkotaan di negara tropis dan subtropis. Saat ini juga diperkirakan ada 390 juta infeksi dengue yang terjadi di seluruh dunia setiap tahun. Terhitung sejak tahun 1986 hingga 2009, WHO mencatat negara Indonesia sebagai negara dengan kasus DBD tertinggi di Asia Tenggara dan tertinggi nomor dua di dunia setelah Thailand (Dewi, 2015). Angka kesakitan (IR/Incidence Rate) DBD di Indonesia pada tahun 2012 hingga 2016 mengalami fluktuasi, antara lain tahun 2012 dengan IR 37,27 per 100.000 penduduk $(90.245$ kasus), tahun 2013 IR 45,85\% (112.511 kasus), tahun 2014 IR 39,80\% ( 100.347 kasus), tahun 2015 IR 50,75\% (129.650 kasus), dan tahun 2016 IR 78,85\% (204.171 kasus). Angka kematian (CFR/Case Fatality Rate) DBD di Indonesia tahun 2012 0,90\% ( 816 jiwa), tahun 2013 CFR 0,77\% (871 jiwa), tahun 2014 CFR 0,9\% (907 jiwa), tahun 2015 CFR 0,83\% (1071 jiwa), tahun 2016 CFR $0,78 \% \quad$ (1598 jiwa) (Kemenkes RI, 2012-2016). Sesuai dengan Rencana Program Jangka Menengah Nasional (RPJMN) 2014-
2019, untuk target IR DBD Nasional yaitu < 20 per 100.000 penduduk dan target CFR Nasional <1\%, sedangkan Indonesia masih jauh dari target nasional tersebut (RPJMN, 2015- 2019).

Angka Kesakitan DBD pada tahun 2018 di Provinsi Riau 13,47\%. Angka kematian (CFR) akibat DBD lebih dari $1 \%$ dikategorikan tinggi. Pada Tahn 2018 Angka Kematian DBD di Provinsi Riau yaitu sebesar 0,87\%. Selama periode tahun 2010 sampai tahun 2016 terlihat jumlah kabupaten/kota terjangkit DBD mengalami kenaikan, namun mulai menurun pada tahun 2017 dan sedikit meningkat pada tahun 2018. Persentase Provinsi Riau tahun 2018 sudah mencapai IR DBD < 49/100.000 penduduk.

Penyakit demam berdarah dapat dicegah dan disembuhkan, sesuai dengan Undang-Undang No 36 Tahun 2009 Tentang Kesehatan pasal 152 menyatakan bahwa pemerintah, pemerintah daerah dan masyarakat bertanggung jawab melakukan upaya pencegahan, pengendalian, dan pemberantasan penyakit menular serta akibat yang ditimbulkannya. Kebijakan Kementerian Kesehatan dalam upaya pencegahan dan pemberantasan DBD yaitu pengendalian vector dari larva sampai nyamuk dewasa melalui pemberdayaan masyarakat dengan utama Pemberantasan Sarang Nyamuk (PSN) 3M plus; surveilans untuk deteksi dini, pencegahan dan pengendalian kasus dan KLB DBD; penatalaksanaan kasus untuk mencegah kematian; dukungan managemen (termasuk anggaran, peningkatan kapasitas SDM dan logistik), kemitraan dalam wadah POKJANAL DBD.

\section{METODE PELAKSANAAN}

Metode yang akan digunakan dalam pelaksanaan ini adalah bentuk pengabdian kepada masyarakat berupa 
penyuluhan dan pendidikan kesehatan. Adapun tahapan pelaksanaan kegiatan yang dilakukan meliputi tahapan persiapan, tahapan pelaksanaan dan monitoring evaluasi. Tahap perisiapan meliputi pertemuan dengan instansi tempat pengabdian masyarakat yaitu di Posyandu Pelita Hati Pekanbaru dan rencana kegiatan apa yang dilakukan. Tahap pelaksanaan meliputi pelaksanaan kegiatan pengabdian masyarakat. Tahap monitoring evaluasi meliputi evaluasi hasil dan kegiatan pengabdian masyarakat berupa penyuluhan dan pendidikan kesehatan 3M Plus Cegah Demam Berdarah.

\section{HASIL DAN PEMBAHASAN}

Kegiatan Pengabdian Masyarakat penyuluhan pada pada perilaku $3 \mathrm{M}$ Cegah Demam Berdarah pada ibu-ibu dilaksankan di Posyandu Pelita Hati RW 11 Kelurahan Sidomulyotimur Pekanbaru. Kegiatan diikuti oleh ibu-ibu yang berjumlah 20 orang, kegiatan dilaksanakan pada hari Jum'at tanggal 15 November 2019 yang dimulai pukul 08.00 WIB sampai dengan selesai.. Bentuk kegiatan pemberdayaan yang dilaksanakan adalah penyuluhan dan pendidikan kesehatan berupa ceramah. Sebelum para ibu-ibu yakni ibu-ibu di Posyandu diberikan penjelasan. Setelah para pengabdi menyampaikan materi para ibu-ibu diberikan pertanyaan. Hasil yang didapat bahwa dari $20 \mathrm{ibu}$-ibu yang mengikuti kegiatan tersebut $50 \%$ ibuibu mengetahui dan sudah melakukan $3 \mathrm{M}$ plus.

Kegiatan penyuluhan $3 \mathrm{M}$ plus dan pendidikan kesehatan berupa ceramah sangat epektif dilaksanakan pada Posyandu Pelita Hati RW 11 Kelurahan Sidomulyotimur Pekanbaru.

Melaksanakan Pemberdayaan Masyarakat dengan memberikan penyuluhan 3M plus Cegah Demam Berdarah merupakan salah satu bentuk kegiatan dalam meningkatkan pengetahuan ibu-ibu di posyandu dalam menerapkan pencegahan demam berdarah dengan $3 \mathrm{M}$ plus.

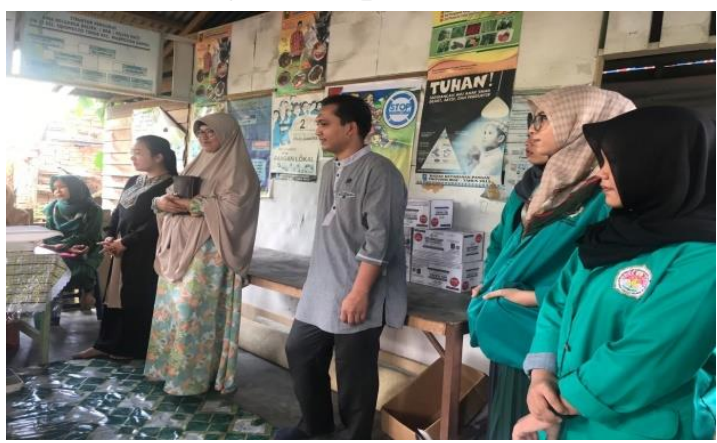

Gambar 1. Memberikan Materi terkait 3M Plus Dapat Mencegah DBD

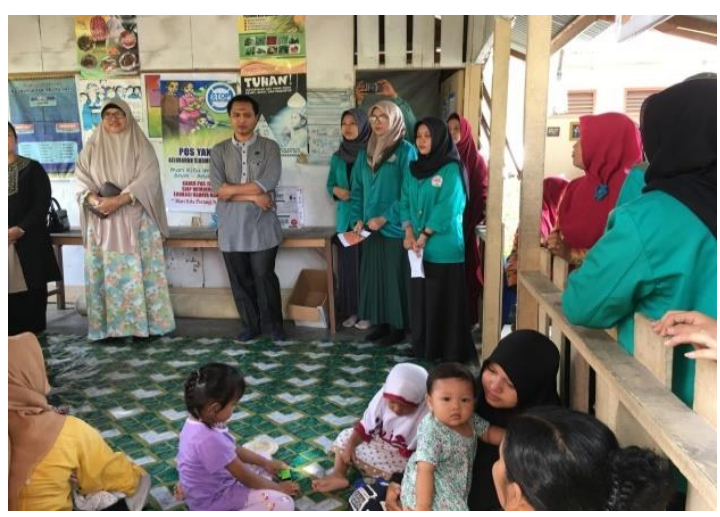

Gambar 3. Mendengar Pertanyaan dari Ibu- Ibu Yang Mengunjungi Posyandu

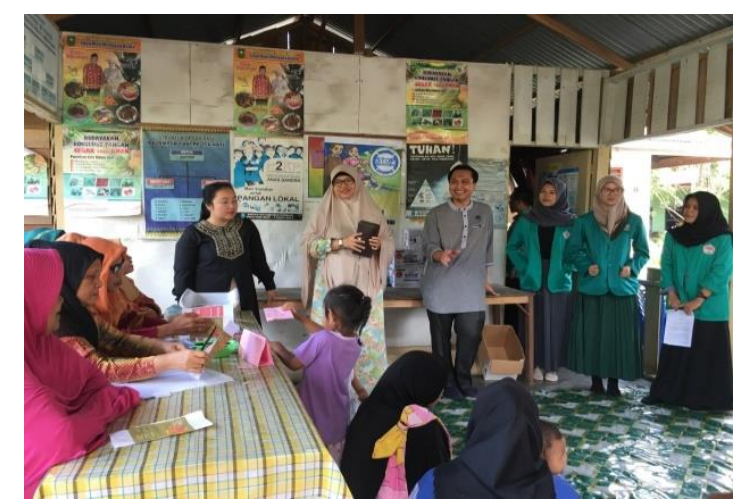

Gambar 2. Menjawab Pertanyaan dari Ibu-Ibu Yang Mengunjungi Posyandu

\section{SIMPULAN}

Ibu-ibu mendapatkan pengetahuan baru dengan diadakan kegiatan Penyuluhan tersebut. Hasil yang didapat bahwa dari 20 ibu-ibu yang mengikuti kegiatan tersebut $50 \%$ ibu-ibu mengetahui dan sudah melakukan $3 \mathrm{M}$ plus. 
Ibu-ibu mengatakan bahwa mereka akan mempraktekkan cegah demam berdarah dengan 3M plus di rumah yang telah mendapatkan pengetahuan pada saat pelaksanaan pengabdian masyarakat.

\section{UCAPAN TERIMAKASIH}

Ucapan terimakasih kami sampaikan kepada Lembaga Penelitian dan Pengabdian Masyarakat STIKes Hang Tuah sebagai pemberi dana dalam kegiatan pengabdian masyarakat yang telah dilaksanakan pada bulan November 2019. Serta ucapan terimakasih kepada Posyandu Pelita Hati Rw 11 Pekanbaru yang telah memberikan kesempatan dalam pelaksanaan pengabdian masyarakat.

\section{DAFTAR PUSTAKA}

[1]. Afriza,Tuti. 2012. Pengaruh Perilaku Masyarakat dalam 3M Plus terhadap Resiko Kejadian Demam berdarah di Wilayah Kerja Puskesmas Labuhanhaji Timur Kabupaten Aceh Selatan. (online).

(Ejournal.Uui.Ac.Id/Jurnal/Tuti_ Afriza-Fzj-Jurnal_Tuti_A.Pdf)

[2]. Ariani, A.P. (2016). Demam Berdarah Dengue (DBD). Yogyakarta : Nuha Medika

[3]. Dinas Kesehatan Provinsi Jawa Tengah. Buku Saku Kesehatan Jawa Tengah 2015. Provinsi Jawa Tengah 2015.

[4]. Dinas Kesehatan Provinsi Jawa Tengah. (2016). Profil Kesehatan Provinsi Jawa Tengah 2016. Semarang

[5]. Dinas Kesehatan Kota Surakarta. (2017). Profil Kesehatan Kota Surakarta 2017. Surakarta : Dinkes Kota Surakarta

[6]. Kementerian Kesehatan Republik Indonesia. (2017). Profil Kesehatan Indonesia 2017. Jakarta
[7]. Kementerian Kesehatan Republik Indonesia. (2018). Profil Kesehatan Indonesia 2018. Jakarta

[8]. Kementrian Kesehatan, Pusat Data dan Surveilans Epidemiologi.Buletin Jendela Epidemiologi : Demam Berdarah Dengue. Jakarta : Kementrian Kesehatan Republik Indonesia, 2015, Buletin Jendela Epidemiologi Volume 2, Vol. II, hal. 48. 2087-1546

[9]. omitasari, D., Saraswati, L.D., dan Ginandjar, P. Perbedaan praktik PSN 3M Plus di kelurahan percontohan dan non percontohan program pemantauan jentik rutin kota Semarang. 1, 32-37, Semarang : Jurnal Entomologi Indonesia, 2012, Vol. Vol. 9 No. 1. ISSN: 1829-7722

[10]. Pratamawati, Diana. (2015) Peran Juru Pantau Jentik dalam Sistem Kewaspadaan Dini Demam Berdarah Dengue di Indonesia, Jurnal Kesehatan Masyarakat Nasional, vol 6; no 6,

[11]. Puskesmas Simpang Tiga. (2019). Laporan Tahunan Puskesmas Simpang Tiga Kota Pekanbaru Tahun 2019. Pekanbaru

[12].Soedarto. (2012). Demam Berdarah Dengue. Jakarta: CV Sagung Seto 